\title{
Brain hydatidosis: report of two cases
}

\author{
A FABIANI, F TREBINI, AND R TORTA \\ From the Neurological Clinic, University of Turin, Turin, Italy
}

SUMMARY Two children affected by cerebral hydatidosis are described. For preoperative diagnostic purposes computerised axial tomography appears currently to be the most suitable procedure. Complete surgical removal of the cyst, with methods preserving its integrity, seems to be the main factor for definitive recovery as the different outcomes in the two cases show.

Hydatidosis is caused by the cystic modification of the larval stage of the Echinococcus granulosus. This tapeworm is commonly present in herbivorous animals such as sheep and goats but only occasionally in man. As mature worm, the parasite lives in the intestine of domestic animals including dogs and cats. As intermediate hosts, the adult human may be indirectly infected by ingestion of the ova, and children may be more easily contaminated by direct contact. The incidence of the disease in the world has a different distribution curve, parallel with sheep breeding, as in sheep $100 \%$ of the cysts are fertile. ${ }^{1}$ In Italy most cases are recorded in the south of the country and islands. Cysts occur most commonly in the liver $(65 \%)$ and lung $(20 \%)$, and intracranial cysts are rare. ${ }^{2}$ In relation to the other space-occupying processes of the brain the frequency ranges from 0.5 to $2 \% .^{3-6}$ In our collection of brain tumours, consisting of about 4000 cases, only two cases of cerebral hydatidosis were identified.

\section{Case reports}

CASE 1

This girl (P V), aged 11 years, lived in a rural area of Sicily. The clinical history started six months before admission and was characterised by headache and motor impairment of the right limbs. Neurological examination showed papilloedema, pyramidal tract signs on the right, and psychic abnormalities. Left carotid angiography

Address for reprint requests: Professor A Fabiani, Neurological Clinic, University of Turin, Via Cherasco 15, 10126 Torino, Italy.

Accepted 14 June 1979 showed a frontotemporal "neoplasm" in the form of roundish avascular mass. General examination and haematological investigations did not disclose other pathological findings, especially concerning liver and lung. At operation, a multilobulated cyst the size of an orange was excised (fig 1a), but during surgery it was not possible to avoid the rupture of the cystic wall. The postoperative course was characterised by a right hemiparesis and progressive psychic deterioration, so that eight months later the patient was readmitted and further surgery carried out. At the second operation several cysts of different size (fig 1b) were present in the parietal region and some of them showed endoventricular growth. In the following weeks the patient progressed favourably, but one year later she was readmitted with symptoms of increased intracranial pressure with intense headache and vomiting, associated with right hemiparesis. At reoperation, many cysts of different sizes were found in the third ventricle. The postoperative course was characterised by progressive deterioration and one year later the patient died.

CASE 2

This boy (D A), aged 11 years, lived in the south of the country, in contact with dogs and goats. The clinical history started seven months before his admission and was characterised by symptoms of raised intracranical pressure with headache and vomiting, followed by left hemiparesis and psychic impairment. On neurological examination, papilloedema was associated with the left hemiparesis. Right carotid arteriography showed a space-occupying process situated in the frontoparietal region. At operation, a rounded cystic mass with a translucent whitish membrane, 
a

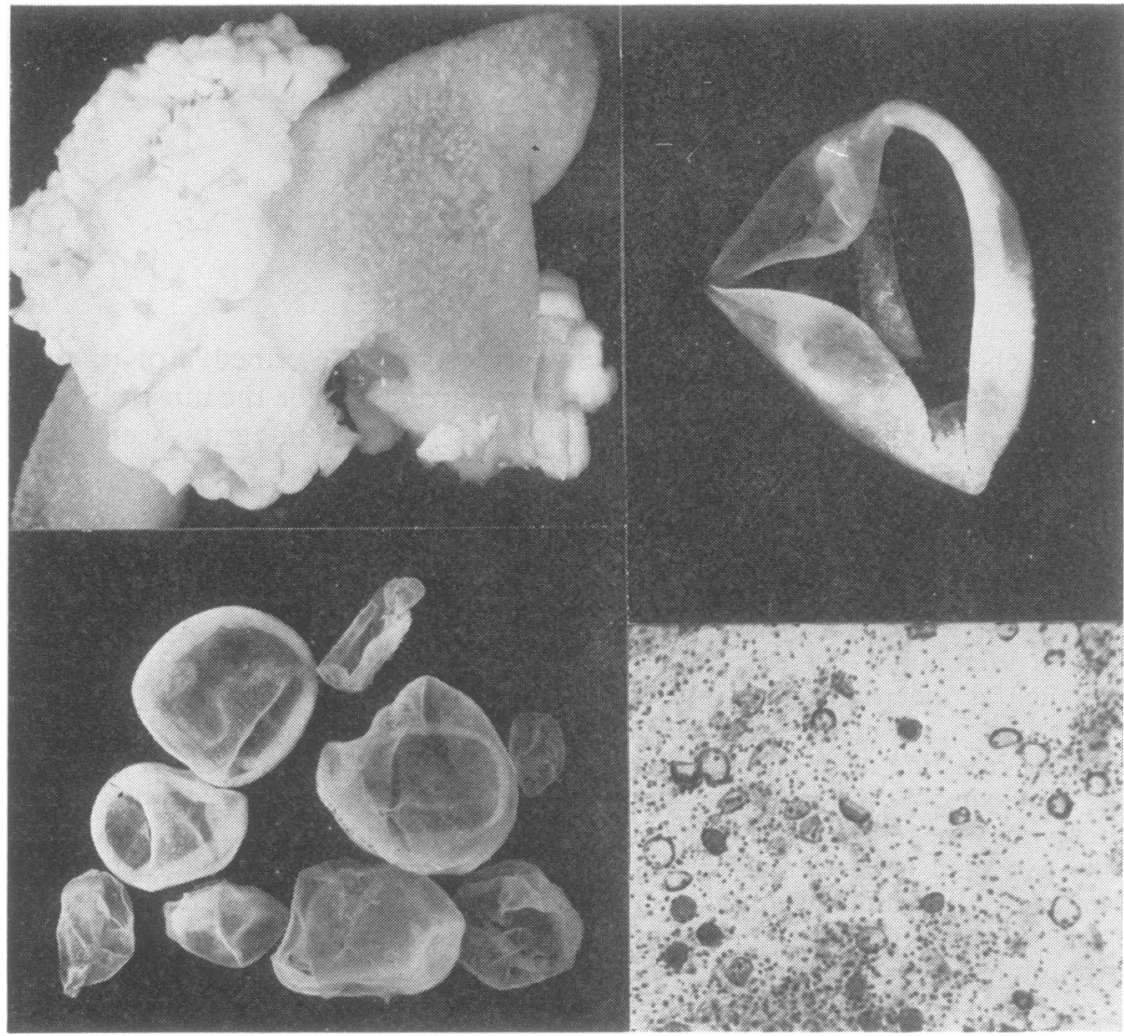

Fig 1 (a) Macroscopic aspects of the ruptured cyst at the first operation, and (b) multiple cysts at the second operation in case 1. (c) Macroscopic aspect of the cyst after postoperative rupture (case 2). (d) Tissue infiltration by several daughter microcysts (case 1). Emat Eos, original magnification $\times 40$.

measuring $80 \mathrm{~mm}$ in diameter, was excised avoiding rupture of the cyst wall (fig 1c). The postoperative course was characterised by a progressive recovery and till now the boy is well.

\section{PATHOLOGY}

At the first surgical exploration in both cases encapsulated masses were found just below the cerebral cortex. In the first case the cyst was in the form of an elongated multilobulated mass with several daughter vesicles in clusters similar to racemose structures (fig 1a). At the second operation there were many distinct parenchymal and ventricular cysts (fig $1 \mathrm{~b}$ ). In the second case there was a single rounded cyst (fig 1c).

On microscopic examination, the cyst wall consisted of three layers. On the outside there was an adventitial fibrous reactive capsule, foilowed by a stratified cuticular layer and internally by a germinative membrane, the source of the daughter vesicles. The contents of the cysts consisted of a clear fluid containing germinative elements, primitive scolices and daughter microcysts (fig 2). The surrounding brain tissue appeared to be compressed with few signs of reaction, except for a narrow zone of demyelination around the adventitial capsule. In the reoperated first case, the histology showed an obvious tissue infiltration by daughter microcysts as well as discrete glial reaction (fig 1d).

\section{Discussion}

Cerebral hydatidosis is the most frequent site of craniospinal infestation, particularly in children in whom brain disease is usually thought to be primary. ${ }^{7-9}$ There is generally a single spherical cyst of large size; rarely the cysts are two or multiple. ${ }^{2}$ When this happens the involvement of the CNS is often secondary to rupture of cysts of the lung or left heart. Therefore it is noteworthy that our first case, initially showing a 


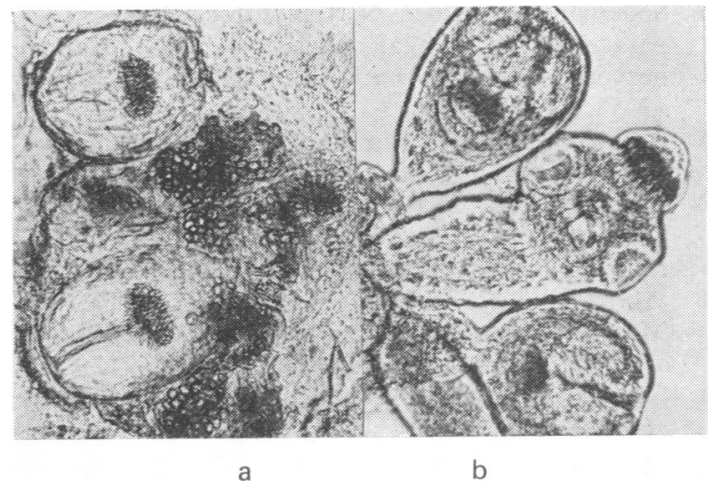

Fig 2 Contents of the cystic fluid: (a) hexacanth embryos with invaginated head and microcysts, and (b) after protrusion of the head the scolex shows obvious suckers and hooklets. Burri, original magnification $\times 160$.

multilobulated aspect, later presented secondary multiple cysts at the second and third operations. The macroscopic feature of the cyst when first seen requires some diagnostic caution owing to its resemblance to cysts of Echinococcus alveolaris (multilocularis). However, form, colour, size, and wall resistance as well as the epidemiology are quite different, as Thierry et $a l^{10}$ have pointed out.

Ventricular dissemination from subdural or intracerebral cysts has sometimes been observed, but the ventricular system is very rarely involved. $^{11}$ In our first case the ventricular dissemination was caused by accidental rupture of the cyst during the first surgical exploration.

Brain hydatidosis is a children's disease, the largest number of cases involving subjects living in sheep rearing areas. In general, there is a single large cyst situated in the subcortical areas of the parieto-temporo-occipital lobes. The clinical picture has the same characteristics as other space-occupying processes, with frequent epileptic seizures ${ }^{12}$ so that diagnosis is very difficult, as symptomatology, electroencephalographic and radiological findings are nonspecific. ${ }^{314}$ Results of several investigations, such as eosinophilia of peripheral blood, and the Casoni and Ghedini-Weinberg reactions, are of limited value. ${ }^{15}$ Likewise, CSF examinations do not furnish useful data for diagnostic purposes. ${ }^{9}$

Among neuroradiological procedures, arteriography and computerised tomography are the techniques of choice. With arteriography it is possible to obtain some peculiar radiographic features represented by an enormous displacement of the cerebral vessels surrounding an avascular roundish area. Moreover, the cerebral vessels have a normal appearance, but often assume a circumferential disposition around the cyst. Arana-Iñiguez and San Julian ${ }^{16}$ pointed out the importance of these findings which may not be considered as pathognomonic changes. ${ }^{17} 18$ On the other hand, pneumoencephalographic studies are not useful diagnostically and are contradicted because of the raised intracranial pressure and the danger of dissemination of the cyst contents. ${ }^{3}$ For preoperative diagnostic purposes, computerised axial tomography appears currently to be the most suitable method for its "almost pathognomonic" features, distinguishable from cerebral abscesses, cystic tumours and arachnoidal cysts, which are the more common and similar lesions. ${ }^{18}$

The method of treatment of cerebral hydatidosis is surgical. Among current operative techniques several procedures that assure the integrity of the cyst have been described. ${ }^{361619}$ Complete surgical removal of the cyst, with methods preserving its integrity, seems to be the principal factor for definitive recovery, as the different courses of our two cases demonstrate.

\section{References}

1 De Carneri I. Parassitologia Generale e Umana. Milano: Casa Editrice Ambrosiana 1968; 131-9.

2 Langmaid C, Rogers L. Intracranial hydatids. Brain 1940; 63:184-90.

3 Anderson M, Bickerstaff ER, Hamilton JG. Cerebral hydatid disease in Britain. $J$ Neurol Neurosurg Psychiatry 1975; 38:1104-8.

4 Paillas J, Tamalet P. Les kystes hydatiques du cerveau. (À propos de deux cas observés chez l'enfant). Méd Trop 1951; 11:89-100.

5 Obrador S, Ortiz Gonzales JM. Revision de cuarenta casos de quistes hydaticos del encephalo. Rev Clin Esp 1960; 79:176-81.

6 Barrucand D, Hermo J, Ourazazi A, Schmitt J, Schmidt C. Les formes neuro-chirurgicales du kyste hydatique. Rev Otoneuroophthalmol 1976; 48:291-311.

7 Phillips G. Primary cerebral hydatid cysts. J Neurol Neurosurg Psychiatry 1948; 11:44-52.

8 Arana-Iñiguez R, Perillo W, Pereda A, Medoc J. Échinococcose des os du crâne. Neurochirurgie 1973; 19:347-72.

9 Adams JH. Parasitic and Fungal Infections of the Nervous System. In: Blackwood W, Corsellis JAN, eds. Greenfield's Neuropathology. Edinburgh: Edward Arnold, 1976: 277-9.

10 Thierry $\mathrm{A}$, Cortet $\mathrm{P}$, Michiels $\mathrm{R}$ et al. Exérèse chirurgicale des localisations cérébrales de 
l'échinococcose multiloculaire. Neurochirurgie 1978; 78:123-8.

11 Asenjo A, Donoso P, Colin E. Tumeurs ventriculaires peu fréquentes. Neurochirurgie 1973; 19:308-12.

12 Filizzolo F, Nastasi G, Morello A. L'echinccocco dell'encefalo. Su sette casi di localizzazione emisferica sopratentoriale. Acta Neurologica 1973; 28:77-84.

13 Arseni C, Marinescu V. Epilepsy in cerebral hydatidosis. Epilepsia 1974; 15:45-54.

14 Bernini FP, Muras I, Tedeschi G. A proposito di due rari casi di pseudoematoma subdurale. Acta Neurologica 1975; 30:42-8.
15 Sodeman TM, Dock N. Laboratory diagnosis of parasitic and fungal diseases of the central nervous system. Ann Clin Lab Sci 1976; 6: 47-55.

16 Arana-Iñiguez $R$, San Julian J. Hydatid cysts of the brain. J Neurosurg 1955; 12:323-35.

17 Samiy E, Zadeh FA. Cranial and intracranial hydatidosis with special reference to roentgenray diagnosis. J Neurosurg 1965; 22:425-33.

18 Abbassioun K, Rahmat H, Ameli NO, Tafazoli M. Computerized tomography in hydatid cyst of the brain. J Neurosurg 1978; 49:408-11.

19 Goinard P, Decuns P. Les kystes hydatiques du névraxe. Rev Neurol 1952; 86:369-415. 